\title{
Computed Tomography Findings of a Dentigerous Cyst Associated with an Ectopic Tooth in the Maxillary Sinus
}

\section{Maksiller Sinüste Ektopik Dişe Bağlı Dentigerous Kistin Bilgisayarlı Tomografi Bulguları}

\author{
Çetin İmamoğlu ${ }^{1}$, Aydin Tunc $\mathrm{Uzel}^{2}$, İsmail Gedi İbrahim ${ }^{1}$, İsmail Mohamed $\mathrm{Ali}^{2}$ \\ ${ }^{1}$ Somali-Türkiye Recep Tayyip Erdoğan Eğitim Ve Araştırma Hastanesi, Radyoloji Kliniği, Mogadishu \\ ${ }^{2}$ Somali-Türkiye Recep Tayyip Erdoğan Eğitim Ve Araştırma Hastanesi, Kulak Burun Boğaz Kliniği, \\ Mogadishu
}

Dergiye Ulaşma Tarihi: 04.08.2019 Dergiye Kabul Tarihi: 25.11.2019 Doi: 10.5505/aot.2019.27676

\section{ÖZET}

Dentigerous kistler bir odontojenik kist türü olup en sık üçüncü molar diş ile ilişkili olarak gelişir. Dentigerous kistler siklıkla asemptomatiktir ancak bazen enfeksiyon, sinüzit veya kemikte ekspansiyon gibi komplikasyonlara neden olabilir. 22 yaşında siyahi erkek hasta, bir haftadır giderek artan sol taraflı yüz şişliği, sol yanak ağrısı ve burun tıkanıklığı şikayeti ile hastanemize başvurdu. Hastanın fizik muayenesinde yüzünün sol tarafında şişlik ve palpasyonla maksiller bölgede hassasiyet mevcuttu. Oral muayenesinde sol maksillar 3. molar dişin yeri boştu. Hastaya paranazal sinüs BT çekildi. BT'de sol maksiller sinüs antrumunu dolduran 26x41 mm boyutlarında alveoler proces defekti ile ilişkili kistik lezyon izlendi. Kistin çevresinde ince kalsifiye bir duvar ve içinde anterior duvarda 3. molar diş mevcuttu. Kistin maksiller sinüsün lateral duvarını erode ettiği ve komşu yumuşak doku planları arasına yayıldığı görüldü. Hasta Caldwell-Luc prosedürü ile opere edildi. Ektopik diş çıkarıldı ve tüm kist içeriği boşaltıldı. Hastanın kontrolde şikayetlerinin geçtiği görüldü.

Anahtar Kelimeler: ektopik diş, maksiller sinüs, dentigeröz kist, bilgisayarlı tomografi

\begin{abstract}
Dentigerous cysts are a type of odontogenic cyst that mostly develops in association with the third molar tooth. Dentigerous cysts are often asymptomatic but sometimes might be complicated by infection, sinusitis, or bone expansion. A 22-year-old black male patient was admitted to our hospital with complaints of 1- week progressive left-sided facial swelling, left cheek pain, and nasal obstruction. Physical examination revealed swelling on the left side of the face and tenderness in the maxillary region with palpation. Oral examination showed emptiness at the site of left maxillary third molar tooth. The patient underwent paranasal sinus CT. CT showed a 26x41 mm cystic lesion associated with alveolar process defect in left maxillary sinus antrum. There was a thin calcified wall around the cyst and a third molar tooth in the anterior wall. The cyst eroded the lateral wall of the maxillary sinus and spread adjacent soft tissue plans. The patient was operated with Caldwell-Luc procedure. The ectopic tooth was removed and all cyst contents were evacuated. The patient's complaints were disappeared at the control.

Keywords: ectopic tooth, maxillary sinus, dentigerous cyst, computed tomography
\end{abstract}

\section{INTRODUCTION}

Dentigerous cysts are a type of odontogenic cyst that is caused by the expansion of dental follicles due to the accumulation of fluid between the crowns of the unerupted teeth and the epithelial components (1). It is the second most common cystic lesion of the jaw after radicular cysts (2). Dentigerous cysts are most commonly associated with the third molar tooth and approximately $70 \%$ occur in the mandible and $30 \%$ in the maxilla (2-3).
Dentigerous cysts are often asymptomatic and usually diagnosed during routine radiological examinations (4-5). Sometimes dentigerous cysts may cause complications such as infection, sinusitis or bone expansion, erosion, and pathological fracture (6).

In this article, we present the computed tomography findings of a dentigerous cyst associated with ectopic tooth in the left maxillary sinus. 


\section{CASE REPORT}

22-year-old black male patient with left-sided facial swelling, pain in the left cheek and nasal obstruction complaints was admitted to the Somalia-Turkey RTE Training and Research Hospital's Ear, Nose and Throat Clinic. The patient's complaints started one week ago and otherwise he has unremarkable clinical history. Physical examination revealed swelling on the left side of his face. There was tenderness in the maxillary region by palpation. Oral examination showed emptiness at the site of left maxillary third molar tooth with edematous gingival and alveolar mucosa in this region. Rhinoscopic examination was normal. The patient was evaluated with paranasal sinus CT. CT showed 26x41 mm sized cystic lesion associated with alveolar process defect in the maxillary sinus (figure 1). There was a thin calcified wall around the cyst and an ectopic tooth in the anterior wall (figure 1 and 2). The root of the upper left 2. molar tooth was extend into the maxillary sinus (figure 3). And the place of third molar tooth observed empty (figure 4).

There was focal thinning, slight outward expansion and cortical irregularity in the region of the ectopic tooth in the maxillary sinus anterior wall (figures 2 and 5). The medial wall of the maxillary sinus was expanded by the cyst and left nasal cavity was partially narrowed (figure 2). The cyst was eroding the lateral wall of the maxillary sinus and extending to the adjacent soft tissue plans (figures 3 and 6). In addition, there were air densities suggesting infection within the cyst (figures 1and 6). There was no aeration in the left ostiomeatal unit, left maxillary, left ethmoid and both frontal sinuses, and they were filled with hypodense soft tissue density (figure 7).

Outpatient antibiotic and analgesic treatment was started and surgery was recommended. When the patient decided to undergo surgery, he was operated with the Caldwell-Luc procedure after his consent (figure 8). The ectopic tooth was removed and all cyst contents were evacuated. The patient's symptoms improved at the control.

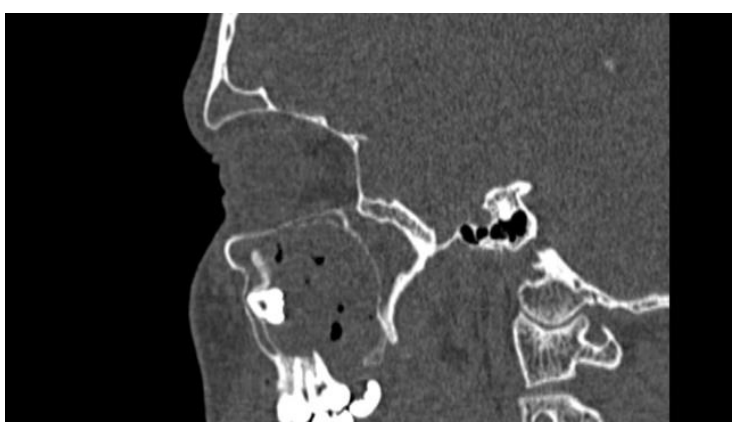

Figure 1: Sagittal computed tomography image of a dentigerous cyst in the left maxillary antrum. Note the thin rim of bone along the inner margin of the true maxillary antral wall. This indicates that the lesion has its origin outside of the antrum.

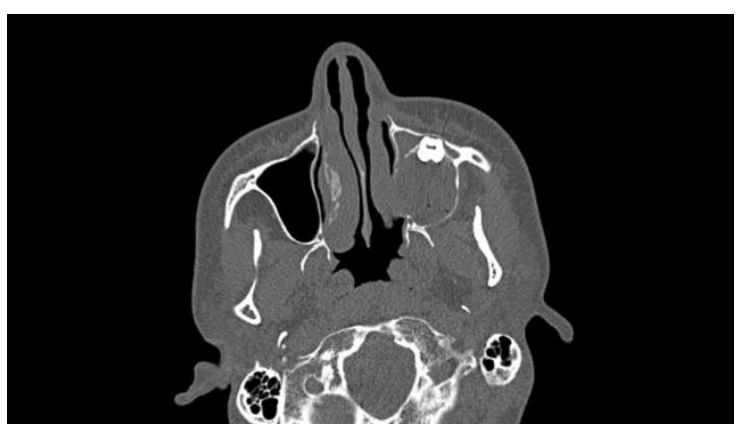

Figure 2: Ectopic tooth in the cyst and thinning and expansion at maxillary sinüs Wall.

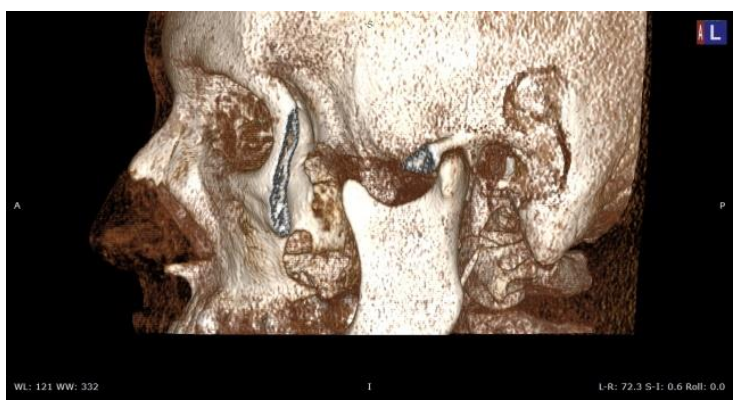

Figure 3: The root of the upper left 2. molar tooth was extend into the maxillary sinüs 


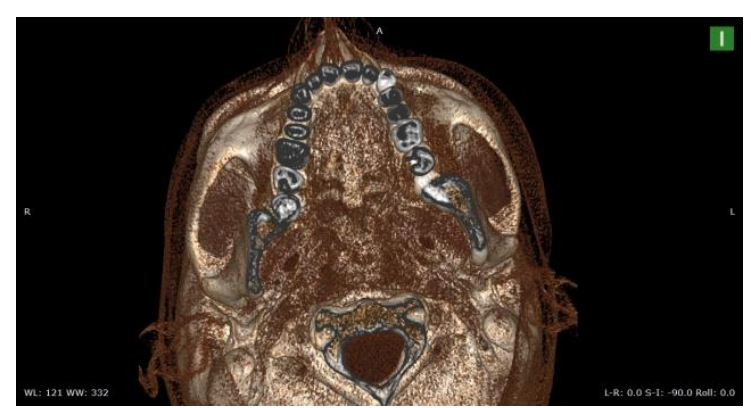

Figure 4: The place of third molar tooth is empty.

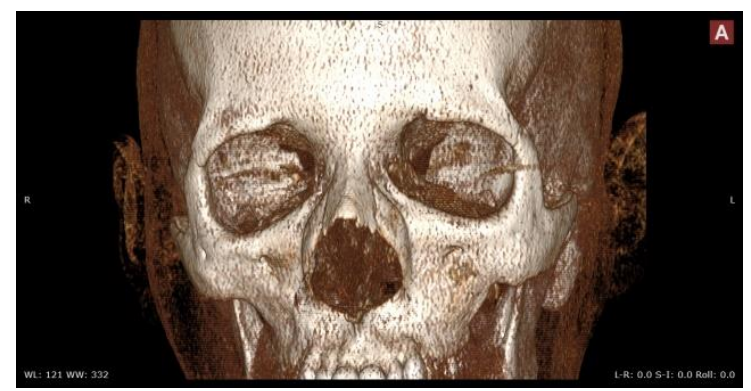

Figure 5: The cortical irregularity of maxillary bone at the region of the ectopic tooth

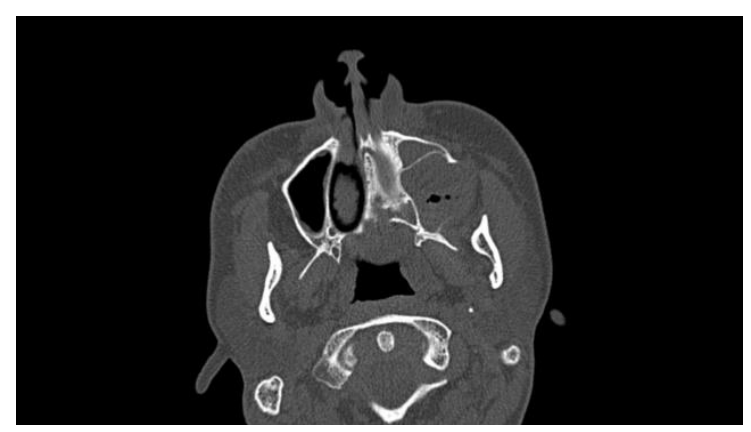

Figure 6:The cyst erode the lateral wall of the maxillary sinus and spread adjacent soft tissue plans.

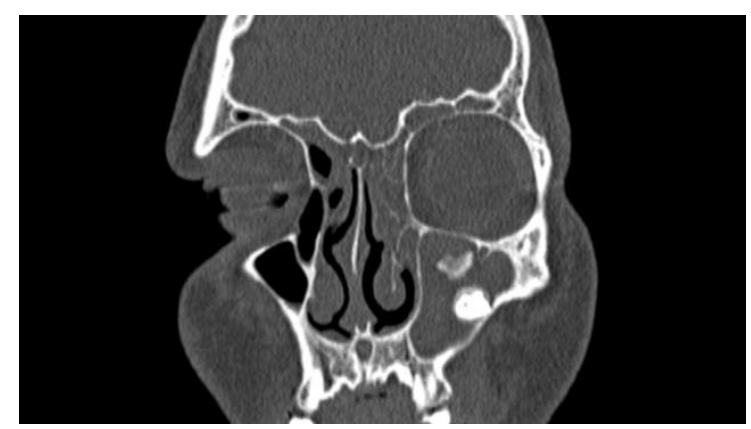

Figure 7: There was no aeration in the left maxillary, left ethmoid and both frontal sinuses.

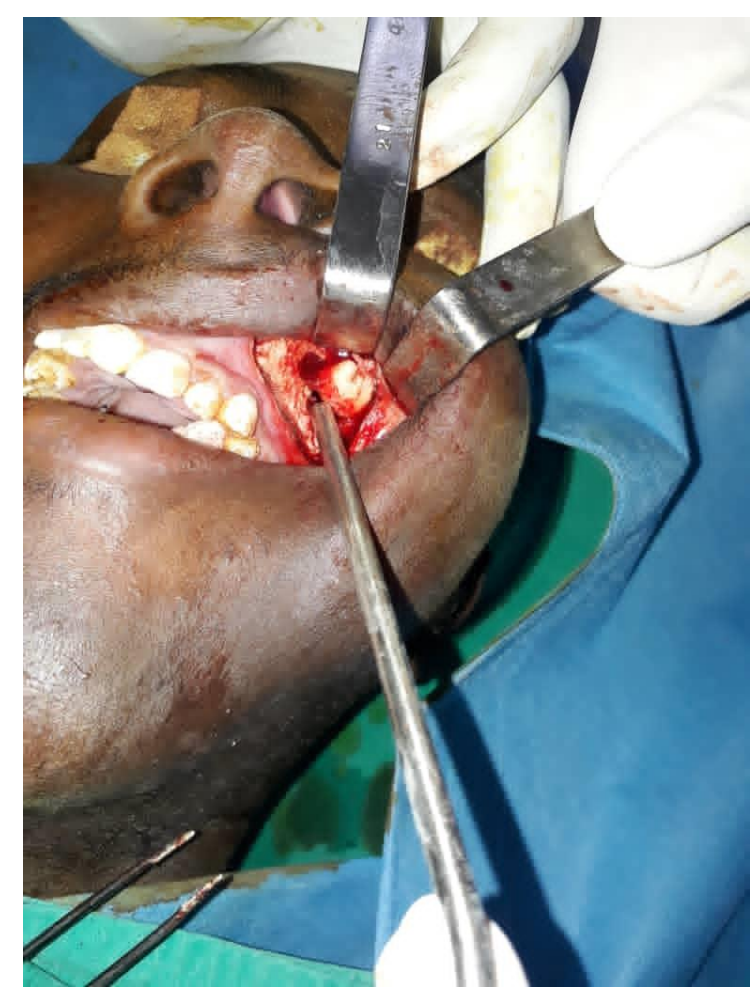

Figure 8: The 3rd molar tooth was removed from maxillary sinus with Caldwell-Luc procedure.

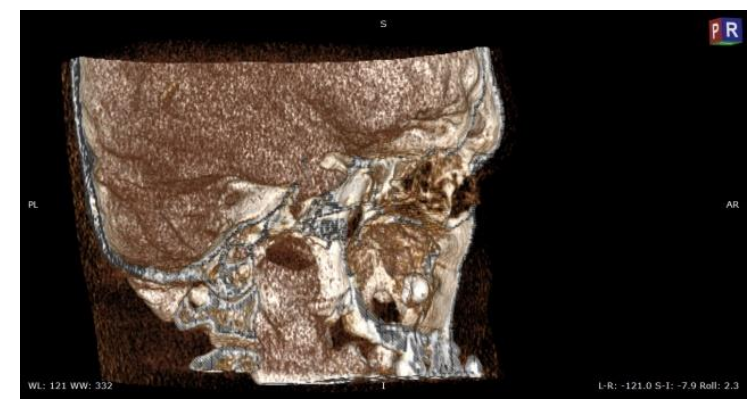

Figure 9:3D CT image of ectopic 3. molar tooth in maxillary sinüs

\section{DISCUSSION}

The etiology of ectopic eruption has not been fully elucidated. Several theories have been proposed that include trauma, infection, developmental anomalies or dentigerous cystlike pathological conditions as in this case (1$2)$. Dentigerous cyst cases are usually seen in the second or third decade of life as in this case (3). The incidence is slightly higher in men than in women (3).

Dentigerous cyst grows slowly and may exist unnoticed for years (4-5-6). 
Symptoms often occur late in the process. Similar to the previously reported cases, we found that the symptoms were pain in the face, unilateral swelling in the face, and nasal congestion (5-7-8-9). We considered the absence of the third molar tooth in physical examination as a very important finding consistent with the literature (7-8-9).

Benign lesions such as hemangioma, osteoma, mucocele and polyp, malignant lesions such as chondrosarcoma and osteosarcoma and foreign bodies should be considered in the differential diagnosis (4). Therefore, radiological examination is very important. Water's radiography, panoramic radiography, and skull radiography are simple, inexpensive methods that can be used in daily practice, but do not provide details where pathologies can be easily bypassed (1-10). CT provides more detailed information in the planning of diagnosis and treatment compared to plain films (10). CT provides superior bone detail as well as predicting prognosis or complications. It helps to determine the size and content of the lesion. An intraantral lesion can usually be differentiated from an extraantral lesion by CT (figure 1). It is also possible to create three-dimensional images with CT to better understand the pathology, or even to perform the virtual surgery in advance (figure 9). In our case, CT alone played an important role in the diagnosis and treatment planning.

The standard treatment for dentigerous cyst is enucleation and extraction of the associated tooth by the Caldwell-Luc procedure (1-2-4-5-7-9). We chose this method for treatment and achieved successful results.

In conclusion, ectopic tooth associated dentigerous cyst in the maxillary sinus is a rare condition. However, ectopic tooth and dentigerous cyst should be considered in the case of sinonasal symptoms, unilateral face pain and swelling on the same side and computed tomography should be taken for diagnosis and treatment plan.

Çıkar Çatışması Beyanı: Yazarlar çıkar çatışması olmadığını bildirmişlerdir.

Finansal Destek: Bu çalışma her hangi bir fon tarafından desteklenmemiştir.

\section{REFERENCES}

1. Abdollahifakhim S, Mousaviagdas M, Ectopic Molar with Maxillary Sinus Drainage Obstruction and Oroantral Fistula ,Iranian Journal of Otorhinolaryngology No.3, Vol.25, Serial No.72, June 2013

2. Kasat VO, Karjodkar FR, Laddha RS. Dentigerous cyst associated with an ectopic third molar in the maxillary sinus: A case report and review of literature. Contemp Clin Dent 2012;3:373-6.

3. Rajendran R, Cysts and Tumors of Odontogenic Origin, Shafer'S Textbook Of Oral Pathology (6Th Edition), Elsevier, Delhi, 4. Chapter, p254-258

4. Küçükkolbaşı $\mathrm{H}$, Esen A, Maksiller sinüste ektopik üçüncü molar diş: Bir olgu sunumu, Selcuk Dental Journal, 2014; 3: 134-137

5. Erdivanlı ÖÇ, Kazıkdaş KÇ, Coşkun ZÖ at. all Antral ektopik diş, Entcase 2015;3:130

6. Agrawal M, Raghavendra PD, Singh B, Agrawal N. Multiple teeth in a single dentigerous cyst follicle: A perplexity. Ann Maxillofac Surg 2011;1:187-9.

7. Kayabasoglu G, Karaman M, Kaymaz R, Nacar A, A Rare Entity Causing Chronic Snusitis: Ectopic Tooth in Maxillary Sinu,Eur J Gen Med 2015;12(1): 86-89

8. Shamsudeen S, et al. "Dentigerous Cyst Involving Maxillary Sinus in Relation to Impacted Maxillary Third Molar-A Case Report". Acta Scientific Dental Sciences 2.6 (2018): 79-81.

9. Dwivedi CD, Dwivedi S, Chaturvedi TP, Sharma N. Maxillary antral mucocoele caused by ectopic canine tooth in maxillary sinus. Eur J Gen Dent 2013;2:83-5.

10. Bodner L, Tovi F,i Bar-Ziv J. Teeth in the maxillary sinüs imaging and management. J Laryngol Otol 1997;111:820-4. 